\title{
MAU'IZAH FOR TEENS IN THE NOVEL SATU BULAN TIGA BINTANG BY UMMU HANI ABU HASSAN
}

\section{(Mau'izah Remaja dalam Novel Satu Bulan Tiga Bintang Karya Ummuhani Abu Hassan)}

\section{Kamariah Kamarudin}

kkamaria@upm.edu.my

Malay Language Department

Faculty of Modern Language and Communication, Universiti Putra Malaysia, Malaysia.

\begin{abstract}
Several efforts have been taken to shape the personality of teens or young adults from an Islamic perspective. One such effort is included in the concept of mau'izah which stresses on the importance of advising and reminding one to work towards virtue, truth and patience. Essentially, the concept of mau 'izah as portrayed in Islam is the core of education, particularly in encouraging young adults to embrace good values. It has been found that mau'izah is not only useful for uplifting the spirit of these young people, but it also provides good reading material for society in general. As such, literary works, especially teen novels comprise reading materials that have the ability to shape the behaviour and personality of youths. Given this, it is the aim of this study to explore mau'izah for teens in the novel Satu Bulan Tiga Bintang by Ummu Hani Abu Hassan in order to determine the extent to which the efforts of advising and reminding youths to pursue virtue are presented by the writer to the readers. Specifically, this study aims to show how the author has utilized the concept of mau'izah in developing an attractive personality among youths guided by Islamic principles in this modern era of science and technology. Needless to say, mau'izah is a pertinent concept as it is the main prerequisite for the development of humanity and the nurturing of a human being.
\end{abstract}

Keywords: mau 'izah, teen, Satu Bulan Tiga Bintang, Ummu Hani Abu Hassan 


\begin{abstract}
Abstrak
Berdasarkan perspektif Islam, terdapat beberapa usaha yang dijalankan untuk membentuk keperibadian anak muda. Satu daripadanya konsep mau'izah, iaitu usaha nasihat dan menasihati, pesan dan memesan ke arah kebaikan, kebenaran dan kesabaran. Konsep mau'izah yang digambarkan dalam Islam ini merupakan tunjang dalam pendidikan khususnya bagi membentuk sahsiah diri golongan remaja kepada nilai-nilai murni. Didapati bahawa mau'izah berguna bukan sahaja dalam pembinaan jiwa anak muda, bahkan dalam proses menghidangkan bahan bacaan yang bermanfaat dalam masyarakat. Sejajar dengan itu, karya sastera khasnya novel remaja merupakan bahan bacaan yang berupaya membentuk perilaku dan sahsiah anak muda. Oleh itu, kajian ini merungkai mau'izah remaja dalam novel Satu Bulan Tiga Bintang karya Ummu Hani Abu Hassan bagi memperlihatkan sejauh mana usaha menasihati dan berpesan kepada kebaikan dan kebenaran ditampilkan pengarang kepada pembaca. Kajian ini jelas memperlihatkan bahawa konsep mau'izah dikemukakan pengarang dengan tujuan membangunkan keperibadian remaja yang unggul mengikut garis panduan Islam dalam arus kemodenan dan teknologi hari ini. Usaha menasihati dan berpesan kepada kebaikan, kebenaran dan kesabaran telah menjadikan konsep mau'izah sebagai syarat utama dalam pembangunan manusiawi dan pembugaran insani.
\end{abstract}

Kata kunci: mau'izah, remaja, Satu Bulan Tiga Bintang, Ummu Hani Abu Hassan

\title{
INTRODUCTION
}

Generally, it can be said that what is needed in order to achieve harmony in today's world is the relationship between an author, his work and the people. Presently, there are many issues facing youths as a result of lack of attention, guidance, supervision, teaching and love. These cause an increase in social problems which can affect their schooling and family relationships. Hence, efforts taken by authors to deliver beneficial messages in literary works should be lauded as these can help to shape a young adult's personality. However, the question is, what kind of works should the young be exposed to? Will racy stories, or ones that use vile and profane language, or even those that present rude and wild characters, uncontrolled fights and conflicts be able to guide these young adults to gain a holistic education?

This state of affairs exists because sleazy and trashy romance novels for teens have mushroomed over time. As a result, teen novels have become inferior in terms of language aesthetics, morals and examples for teens. 
Irresponsible publishers should be blamed as they are not using the Malay literary world to disseminate good examples, truth and beauty according to Islamic guidelines. Instead, they are bent on destroying the younger generation's personality because of their obsession with trashy novels, those that are currently flooding the market. For example, novels revolving around physical love, filled with words like "cinta", "love", "sayang" and so on are constantly being republished. Similarly, novels that deal with murders, fights and cruelty and those that use harsh and abusive words such as "sial" (damn), "babi" (pig), "celaka" (shit) "bodoh" (stupid) are reprinted. This is not only a problem for Malay literary researchers but for parents who are unaware that such books are making their way into the children's hands.

It is therefore extremely important that quality books are published, not only in terms of the issues and problems discussed, but also where language, style and lessons to be learnt are concerned. This is in line with the Islamic viewpoint which entrusts authors to convey something that is beneficial to readers, especially youths. An author, his work and the people are the means by which the young can be guided to walk on the path of virtue, truth and beauty. Hence, this paper will explore mau'izah for teens through the study of the novel Satu Bulan Tiga Bintang by Ummu Hani Abu Hassan. First, the paper will briefly examine the development of teen novels, then it will elaborate on the meaning of mau'izah in Islam, and finally, it will analyse mau'izah in the novel Satu Bulan Tiga Bintang.

\section{THE DEVELOPMENT OF TEEN NOVELS IN MALAYSIA}

It is an interesting phenomenon that teen novels have grown exponentially in Malaysia. This is due to the enthusiasm of local authors who produce works that can deliver important messages to the readers. According to Othman Puteh ${ }^{1}$ (1989, p. 45), basically teen literature should function as an educational as well as an entertainment tool. In fact, teen literature, especially teen novels normally portray or discuss issues regarding teen behaviour, whether right or wrong, good or bad and whether something should be done or not, ${ }^{2}$ and at the same time be capable of expanding the readers' mind towards the material being read.

Apart from that, it is found that the teen novel developed in the country when researchers ${ }^{3}$ began to study the history, genealogy and the differences between novels such as children's novels and teen novels. Studies have shown that the local teen novels have benefited the world of books in the 
country because it is able to shape the personality of youths. Teen novels have not only managed to inculcate the reading habit in youths, it has in fact opened up the academic researchers' world to study teen novels in greater depth. With the passage of time, a variety of initiatives have been devised by the publishers to encourage authors to write. These are some of the factors which have contributed to the development of teen novels:

1. Awareness on the part of authors to produce good works for readers. It is obvious within the reading public that there is great competition from popular and erotic novels.

2. Awareness on the part of local publishers to publish quality books for young adults. Among the publishers that focus on quality in its themes and issues, language, style and message are Dewan Bahasa dan Pustaka (DBP), National Institute of Translation Malaysia, Utusan Publications $\&$ Distributors Sdn. Bhd, PTS Sdn. Bhd, Galeri Ilmu Sdn. Bhd, Telaga Biru Sdn. Bhd and others.

3. Holding of competitions, contests and literary awards in the country. For example, Malaysia's Premier Literary Prize, Utusan Group-ExxonMobil Literature Award, Islamic-oriented Novel Writing Competition, Teen Historical Novel Writing contest and others.

Together, the above factors have contributed to the dramatic growth of teen novels in the country, an interesting subject to be studied. Many initiatives given to authors have helped to motivate them to write. From another perspective, the rapid growth of popular teen novels ${ }^{4}$ especially indie books, those that are erotic and vulgar have driven some authors to produce works of value as they feel it is their responsibility to write and disseminate meaningful lessons to society. This is evident among Muslim authors who write for young adults in order to counter the contaminating influences which are spreading. Some of these authors come from a religious background, therefore they are aware of their role in conveying religious lessons through their works.

With this in mind, it is the aim of this study to explore the concept of mau'izah as used by the author in the novel Satu Bulan Tiga Bintang by Ummu Hani Abu Hassan. Generally, in Islam, Mau'izah means giving advice, lessons and reminders to mankind, especially young adults who need to be 
guided by good values in order to help them live a righteous life. Parents' task of educating teens with the right values is challenging because of distractions arising from advances in science and technology. It is believed that reading literary works that inculcate religious values can help them live a much more peaceful and harmonious life. However, before one tries to understand a good piece of work, one has to consider the background of the author. In this context, the authors who have been exposed to religious education, especially those who study religion and are prolific in writing about Islamic values are in a good position to disseminate elements of advice, lessons and reminders about religion in their works.

Hence, in order to prove the above proposition, the study chooses to study the author Ummu Hani Abu Hassan and her novel. The author who hails from Kedah received a religious education throughout her schooling until postgraduate level. She holds a Master degree in literature and has also embarked on a doctoral study in the field of Malay-Islamic literature. Guided by the concept of mau 'izah, this study will examine her novel Satu Bulan Tiga Bintang, hailed as appropriate reading material for teens, in order to find out how she disseminates advice, teaches and provides reminders in her novel.

\section{MAU'IZAH FROM THE ISLAMIC PERSPECTIVE}

It is found that mau'izah is an approach or method of propagating the Islamic religion. The word mau'izah originates from the word wa'adza ya'idzuwa'adzan-idzatan which means providing advice, guidance, education and reminders. ${ }^{5}$ In addition, mau 'izah also functions to convey good values in appropriate language, in a manner that is acceptable, pleasant, touching, honest etc. It also teaches readers to shun harsh behaviour and not to be judgmental, that is always looking for people's mistakes. ${ }^{6}$ The concept mau'izah is detailed as follows:

(1) Good lessons and advice, deterring bad acts through tarhib and targhib (encouragement and motivation); clarification, explanation, language style, reminders, speech, example, instruction and prohibitions in a subtle way.

(2) Bi al-mauizhah al-hasanah is through lessons, explanation, speech, reminders, instructions in a language style that touches the heart.

(3) In symbolic language and meanings, forewarnings, signs, promises, indications, guides and examples that are beneficial through al-qaul al-rafoq (gentle speech full of love). 
(4) With gentleness, touching the heart and increasing good deeds.

(5) Through a piece of advice, guidance and instruction for beneficial gains. Done in a good and responsible way, warm, communicative, easily absorbed and affecting the heart and soul.

(6) A phrase full of love and gentleness right from the heart so that it affects the soul, not through conflict or deterrence like jeering, insulting, isolating or accusing, can melt even the hard-hearted and tame the wild soul.

(7) With gentle words that are softly spoken, in stages and full of love in the context of religious propagation that can make someone feel valued as a human being until he/she can respond positively. ${ }^{7}$

In fact, the Qur'an contains many chapters that talk about mau'izah to give reminders and lessons to the faithful. Among them are Surah alBaqarah verses 66 and 275, Surah ali-Imran verse 138, Surah al-Maidah verse 46, Surah al-A'raf verse 57, Surah an-Nahl verse 125 and Surah an-Nur verse 34. As explained in the chapter Surah al Baqarah verse 66, in the translation: "And we made it a deterrent punishment for those who were present and for succeeding generations and as an admonishment for those who fear Allah".

Apart from that, Surah ali-Imran verse 138 also conceptualizes mau'izah in the following translation: "The Qur'an is an exposition to all mankind and is also the guidance and lesson for those who fear Allah". Surah Al-Maidah verse 46 states the following, as revealed in the translation:

"We send Isa, the son of Mariam to follow the way of the prophets (the prophets of Israel), confirming the Torah that had been revealed before him and We gave him the Injil which is guidance and light and clarifies and confirms the truth that had been revealed in the Torah, a guidance and admonition to those who fear Allah".

The chapter Surah al-A'raf verse 52 states as in this translation:

"Verily We send them a Scripture (Qur'an) which we have explained in detail from knowledge that encompasses everything, to become a guidance and a blessing for those who believe".

In fact the chapter Surah an-Nahl verse 152 further illustrates the importance of mau'izah in a person's life, as revealed in this translation: 
"Invite to the way of Your Lord ( O Muhammad) with wisdom and good instruction and argue with them in a way that is best. Indeed your Lord is most knowing of those who have strayed from His way and those who are rightly guided".

The chapter Surah an -Nur verse 34 states in this translation:

"Verily, We have sent down for you verses that give clear guidance and cited examples (stories and news) of those who have gone before you to serve as a warning and admonition for those who want to believe".

The above translated examples of several chapters clearly show that mau'izah is mentioned in the Qur'an. These examples also show that mau'izah is greatly emphasised in the lives of humankind. Advice, reminders and lessons that have been put forward can strengthen the element of dakwah and education in mau'izah for the sake of creating vicegerents of Allah on earth and for the benefit of mankind.

\section{MAU'IZAH FOR TEENS IN THE NOVEL SATU BULAN TIGA BINTANG}

\section{(a) Phrase/expression}

Well-phrased and beautiful expressions are very important in a work of literature. This is so because an expression or phrase can raise a reader's enthusiasm to continue reading, and therefore gain some benefit from the book being read. Hence, in the context of educating to achieve mau 'izah, a carefully phrased and wise expression is valuable in our lives, especially in producing works of art. Based on the novel, Satu Bulan Tiga Bintang, the author is seen to have written phrases that can inspire the hearts of the readers, especially the younger generation to move towards developing good values in their lives. This can be observed through the language used and the style of writing shown by Ummu Hani Abu Hassan in the 179-page novel. The use of beautiful language and style can touch the hearts of the readers among the younger generation and adults because this novel is able to inject feelings of humanity and remorse in the readers. This can be seen in the following quotation:

Hari ini cahaya hidup saya pergi tanpa meminta izin. Baharulah saya tahu bahawa cahaya itu bahkan apa-apa yang saya ada pun adalah milik Allah. 
Dia maha berkuasa pada setiap sesuatu, yang hidup mahupun tidak. Ibu adalah sebahagian milik Allah. Saya akui itu. Tetapi air mata saya tidak dapat disabarkan. Ia tidak kering kerana cahaya yang menyinarinya telah tiada. Ibu!

(Satu Bulan Tiga Bintang, 2009, pp. 1-2)

[Today the light of my life has gone, without my permitting it. Now I know that light or anything that I have for that matter belongs to Allah. He is the almighty, and has power over everything, living or otherwise. Mothers are part of what belongs to Allah. I acknowledge that. But my tears cannot be prevented. They will not dry up because the light that shone on it is gone. Mother!]

The phrase "light of my life" that refers to the late mother of the main protagonist, Umairah and the phrase "mothers are part of what belongs to Allah" can be seen as advice, reminder and lesson for the readers, especially youngsters about the importance of appreciating and loving the human being who gave birth to them. Apart from that, the novel also employs beautiful language and style which can be a form of advice, reminder and lesson on death. The author presents the character of a mother who has full conviction in Islam and a strong belief about destiny and death. The mother's stand which is full of conviction and belief in God's will in matters of life and of death is passed down to her youngster, Umairah in a subtle and wise manner. Therefore, the phrases couched in a language and style used by the author are able to bring about mau ' $i z a h$ in a religious life for the readers, especially the young adults.

"Sayang, kita tidak dapat mengubah jadual Tuhan. Sekalipun ibu berusaha untuk setia di sisi kalian, kalau Allah memanggil ibu, kalau Rasulullah SAW menawarkan tempat bersama baginda di sana, ibu lebih memilih Allah dan Rasul, nak. Itu kewajipan kita sebagai manusia, iaitu mencintai Allah dan Rasul-Nya lebih daripada yang lain." Ibu bersuara yakin. Ketika menyebut cinta kepada Allah dan Rasulullah SAW, suara ibu bergetar penuh pengharapan.

(Satu Bulan Tiga Bintang, 2009, p. 5)

["My dear, we cannot change what God has planned. Although I try to be at your side, if God calls me back, if the Prophet offers me a place beside him, I will choose Allah and the Prophet, my child. That is our duty as a human being, that is to love Allah and His Prophet more than others." Mother's voice is full of conviction. When talking about her love for Allah and His Prophet, her voice trembles, full of hope.] 
This cautious and wise manner of conveying something when educating children, using expressions that touch the heart, are also found in the novel Satu Bulan Tiga Bintang. For example, the author presents dialogues that are filled with advice, lessons and reminders in delivering the message to its readers. In this novel, the way a wise mother raises and teaches her children to become good and pious human beings imparts mau'izah to the readers. This novel also presents dialogues that can instill remorse and feelings of humanity between a mother and child in a harmonious family relationship. The author uses words like "my child", "a good daughter" and "my dear" each time the mother phrases her dialogues with her children and this approach demonstrates the use of advice, lessons and reminders about a family situation which should become a guide for the readers:

\begin{abstract}
"Om, jadilah anakyang solehah," ulangnya lagi. Saya tidak terkata. Pesanan itu sangat sebati dan selalu. Kepada Allah saya memohon kekuatan untuk menjadi anak seperti yang dimahukan ibu; anak solehah!

"Bukan sahaja bijak dalam pelajaran, tetapi berkelakuan baik pada semua orang. Anak solehah mesti kuat jiwanya dan tahan segala cabaran. Paling penting mentaati segala perintah Allah dan Rasulullah SAW. Boleh, sayang?" Ibu kembali merenung dan menatap mata saya ...
\end{abstract}

(Satu Bulan Tiga Bintang, 2009, pp. 5-6)

["Om, be a virtuous daughter," she repeated. I was speechless. The reminder has been constant and frequent. I pray to Allah to give me strength to become the kind of daughter that my mother wants; a virtuous one!

"Not only good in studies, but be of good behaviour to everyone. A virtuous child must be strong-hearted and face challenges. Most important, she must follow all of Allah's and His Prophet's instructions. Will you my dear?" Mother again gazed at me and looked into my eyes ...]

In addition to the language and style presented through dialogues between mother and child, the author also uses inspirational and motivational words to guide the readers. In the novel Satu Bulan Tiga Bintang, there are symbols such as "stars" and "moon" which the author uses to inspire youngsters to love their mothers. In this novel, although the mother has died, her child Umairah's love for her is deeply embedded in her heart. In fact, Umairah tries to become a virtuous child to fulfil her mother's wishes. The expressions of advice, lessons and reminders that can instill love in these teenagers for 
their mothers are clearly presented by the author in the phrases "to be a youth who is strong" and "the strength, tenacity and warmth of my mother's love throughout her life will I make as my talisman to go through mine". These expressions that are well thought out and wise can be a source of inspiration for the readers, especially the young adults to become useful human beings to society and religion.

Saya menutup tingkap, melepaskan bintang-bintang terus menceriakan malam. Saya harus kuat untuk menceriakan hidup saya sendiri. Besok akan hadir dan saya berjanji mahu menjadi seorang remaja yang tabah. Walaupun ibu hilang dari pandangan kami, ibu tetap hidup di hati kami semua. Ketabahan, kegigihan dan kehangatan kasih sayang ibu sepanjang hidupnya akan saya jadikan azimat meredah usia kehidupan.

(Satu Bulan Tiga Bintang, 2009, p. 11)

[I close the window, releasing the stars that brighten the night. I must be strong to brighten my own life. Tomorrow will come and I promise to be a youth who is strong. Although mother has gone from our sight, mother still lives in our hearts. The strength, tenacity and warmth of my mother's love throughout her life will I make as my talisman to go through mine.]

\section{(b) Act or Behaviour}

In the context of educating and propagating religion, the importance of an act in showing mau'izah to young adults is something basic that should be taken in all seriousness. This is because a noble act can inspire a youth to become as noble in his daily life. In relation to this, acts through advice, lessons and reminders are really needed in educating and propagating religion to support the shaping of a noble character and personality.

The plot revealed in the novel Satu Bulan Tiga Bintang, demonstrating the noble act of a mother, father or an adult towards a teenager can be an example that benefits the readers. For instance, the character of Abah, a goodnatured father sending Umairah or as she is lovingly called Om to school creates a feeling of joy in the child's heart. The author shows that Abah's act of shouldering his responsibility well although his wife has just died highlights his personality as a responsible man and father in carrying out his duties towards his teenage daughter. The daughter's character is shown as happy and comfortable with her father's act of sending her to school every day as well as the kind words he expresses such as : "Om, be careful when 
you are in school, my dear" These gentle words raises the young girl's spirit with mau'izah in education and propagating religion.

Pukul satu Abah ambil Om," kata Abah. Keretanya diparkirkan di hadapan pintu pagar sekolah. Para pelajar berjejeran masuk ke bangunan kelas, ada yang seperti saya, dihantar ibu bapa. Tangan Abah saya raup dan kucup. Abah kemudian menepuk kepala saya dan bersedia untuk bergerak semula. "Om, baik-baik di sekolah ya sayang," pesan Abah sebelum beredar. Saya berdiri tegak, cuba mengambil nafas pagi ...

(Satu Bulan Tiga Bintang, 2009, p. 15)

["I will come and pick you up at one o'clock, Om," said Abah. His car was parked in front of the school gate. Students were walking to the classrooms, some like me, were sent by parents. I grasped Abah's hand and kissed it. Abah then patted my head and got ready to depart from there.

"Om, take care while in school, my dear" Abah reminded me before departing. I stood straight, trying to breathe in the morning air ...]

Other than portraying the personalities of Abah (father) and Ibu (mother) in the effort to convey advice, lessons and reminders about families, this novel also highlights the character of Ustazah Nuridah as a teacher who is very caring about her teenage students as she continuously advises them to be good and well-mannered. In this context, Ustazah Nuridah is seen as applying wisdom in teaching the teenagers by using gentle words and doing kind acts. Ustazah Nuridah guides the teens by praising the girls through similes and gracious words, demonstrating that it is important and well respected in Islam to act that way. This clearly shows that the advising, teaching and reminding approach has been employed by the author in the novel as seen in the following example:

"Ustazah bahagia anak-anak murid Ustazah cantik seperti mawar. Tetapi ustazah cemburu apabila kecantikan itu tidak dibaluti bungkusan indah. Bukankah sesuatu yang cantik jika dibalut dan dibungkus kemas itu lebih mahal?" kata Ustazah Nuridah.

(Satu Bulan Tiga Bintang, 2009, p. 51)

["I am happy my students are as beautiful as the rose. But I am jealous if that beauty is not wrapped in a beautiful cover. Isn't something that is beautiful, if covered and packaged neatly be more expensive? said Ustazah Nuraidah.] 


\section{(c) Action}

In order to realise mau'izah, the element of action also plays a major role in the lives of human beings attempting to achieve effectiveness in society. One's actions in disseminating good values through mau'izah shows an author's commendable efforts in educating teens in society. This is achieved through the praiseworthy and fast actions by religious propagators in conveying messages of advice, reminders and lessons to its target group, the young adults.

In this regard, the novel has presented various actions by the main or supporting characters to highlight mau'izah that has been built up by the author in her book. The character of Ustazah Nuridah is presented as a noble character, suitable for her role as a religious teacher who endeavours to teach teens good values. For the purpose of fulfilling her responsibility as an educator in the religious discipline, Ustazah Nuridah is shown as a $d a^{\prime} i$ (religious propagator) who works diligently in guiding the young students. One example is Ustazah Nuridah's act of giving inspirational talk, which contains advice, lessons and reminders to Umairah, the teen who had just lost her mother. Through gentle discussions with Umairah when she called the latter to the teachers' room she was able to fathom the teen's sadness after her mother's recent death. Therefore the action taken by Ustazah Nuridah is viewed as an act of mau'izah guiding the teen to become a virtuous daughter and even a reformer after that. This novel has shown an action which is clearly needed in the context of mau'izah such as advice, lessons and reminders for readers in general and teenagers.

"Anak solehah ni peranannya amat besar. Dia menjadi contoh dan kekuatan kepada orang lain," kata Ustazah Nuri. Saya mengerutkan dahi. Apakah tujuan sebenar Ustazah Nuri memanggil saya ke bilik guru? Adakah sekadar mahu bertanyakan matlamat saya menjadi anak solehah? Ah! Mungkin ada sesuatu yang lain. "Om, ketika orang lain ditimpa musibah, anak yang solehah akan matang menghadapinya. Dia tidak akan terjerumus dengan emosi bahkan memperbanyakkan sabar. Misalnya, jika kawan-kawan diserang histeria, anak solehah tak akan menjerit macam orang lain, dia akan baca al-Quran dan menenangkan kawan-kawannya. Betul tak?" tanya Ustazah Nuridah. Saya mengangguk. 
["A virtuous daughter has a very big role to play. She is an example and a source of strength to others," said Ustazah Nur. My brow crinkled. What is Ustazah's real aim in calling me to the teachers' room? Is it only to ask me about my goal to become a virtuous daughter? Ah! Maybe there is something else. "Om, when others are faced with a catastrophe, a virtuous child will face challenges in a mature way. She will not be swayed by emotion, instead she faces it with patience. For example, if one's classmates are attacked by hysteria, the virtuous child will not scream like the others, she will recite the Qur'an and pacify the others. Isn't that right?" Ustazah asked. I nodded.]

Apart from the characters and personalities of Ibu, Abah and Ustazah Nuridah as the main protagonists in carrying the concept of mau'izah in the novel, the character of Nenek (grandma) who is Umairah's maternal grandmother is also introduced by the author. It is revealed that Nenek is Umairah's source of strength in beginning the next phase of her life as the only daughter in a family who has just lost their mother. Grandma's action of praising Umairah's efforts to cook and prepare a menu which she had taught successfully has conveyed mau'izah to the young girl. Grandma's action of guiding her granddaughter carefully and wisely to become a girl who can manage a household although still in her teens has brought about useful advice, lessons and reminder to the readers who will then attempt to emulate the girl.

"Om, Nenek tak sangka Om ni cepat belajar. Betul macam arwah Ibu Om dulu. Bertuahlah Abah dapat seorang anak perempuan macam Om ni, "kata Nenek. Dia mula menyuap nasi menggunakan sudu. Saya hanya memerhatikan nenek. Selera saya menjadi penuh dengan penghargaan Nenek.

(Satu Bulan Tiga Bintang, 2009, p. 46)

[ "Om, grandma didn't think you would learn so fast. You are exactly like your late mother. Your father is lucky to have a daughter like you." She began eating rice with a spoon. I simply observed her. I felt full hearing Grandma's words of praise.]

\section{CONCLUSION}

The discussion of the novel Satu Bulan Tiga Bintang clearly shows that mau'izah for teens has been developed by the author in her work. The author uses phrases, acts and actions by the characters and their characterizations to 
bring out mau'izah for teens in the novel. The characters of the late mother (Ibu), father (Abah), Ustazah Nuridah and grandma (Nenek) as good-natured, cautious and wise in expressing their words convey mau'izah that can benefit youngsters. Human beings are naturally inclined and respond well to advice, reminders and lessons that are gently and cautiously delivered in the process of teaching them to become the vicegerents of Allah on earth. In fact this attribute is what the religion demands of human beings, and therefore, in education there has to be guidance and nurturing that advocates patience, sincerity and serenity. This is in accordance with the efforts for dakwah or propagation of Islam, a noble effort which should be practiced by pendakwah.

Therefore, it is clear that Ummu Hani Abu Hassan whose experiences as a teenager and armed with a knowledge of dakwah or Islamic propagation has worked towards presenting mau'izah for teens for the readers of her novel Satu Bulan Tiga Bintang. Although she has not been proclaimed the winner in any writing contests, she has continued to express the good values needed by humanity. These good values have been used as the support for dakwah efforts in society and is greatly emphasized in all aspects of life. This is what the author crafted in her teen novel for the purpose of guiding teenagers towards the pure religion, without being distracted by the explosion of information technology and the effects of globalization in today's world.

\section{NOTES}

1 Othman Puteh. (1989). Sastera remaja ditinjau daripada beberapa perspektif. Kuala Lumpur: Dewan Bahasa dan Pustaka, pg. 45

2 Nor Raudah Siren. (2006). Falsafah diri remaja dalam novel remaja Melayu. Kuala Lumpur: Dewan Bahasa dan Pustaka, pg. 11

3 There are 12 articles in books discussing children's and teen novels, See Othman Puteh and Abdul Ahmad (comp.), 1984. Sekitar Sastera Kanak-kanak dan Remaja, Kuala Lumpur: Dewan Bahasa dan Pustaka.

4 Researcher has done further discussion before this. Refer Kamariah Kamarudin, 2009. "Antara komersialisme dengan intelektualisme dalam novel Getaran Rindu" in Jurnal Pengajian Melayu, Vol. 20. Kuala Lumpur: Akademi Pengajian Melayu, Universiti Malaya.

5 M. Munir. (2006). Metode dakwah. Jakarta: Kencana, pg 15

6 Muhammad Hizbullah. (2014). Konsep Mau'izhah Hasanah dalam al-Qur'an. (Unpublished MA Thesis in Communi, Jakarta: Universitas Islam Negeri Syarif Hidayatullah, p. I

7 Asep Muhidin. (2002). Dakwah dalam perspektif al-Qur'an. Bandung: Pustaka Setia, pgs 165-166. 


\section{REFERENCES}

Al-Qur'an mushaf Malaysia dan terjemahan. (2007). Shah Alam: Yayasan Restu. Asep Muhidin. (2002). Dakwah dalam perspektifal-Qur'an. Bandung: Pustaka Setia. Kamariah Kamarudin. (2009). Antara komersialisme dengan intelektualisme dalam novel getaran rindu. Jurnal Pengajian Melayu (Jilid 20). Kuala Lumpur: Akademi Pengajian Melayu, Universiti Malaya.

M. Munir. (2006). Metode Dakwah. Jakarta: Kencana.

Muhammad Hizbullah. (2014). Konsep Mau'izhah Hasanah dalam al-Qur'an. (Unpublished MA Thesis in Comunication). Jakarta: Universitas Islam Negeri Syarif Hidayatullah.

Nor Raudah Siren. (2006). Falsafah diri remaja dalam novel remaja Melayu. Kuala Lumpur: Dewan Bahasa dan Pustaka.

Othman Puteh dan Abdul Ahmad (penyelenggara). (1984). Sekitar sastera kanakkanak dan remaja. Kuala Lumpur: Dewan Bahasa dan Pustaka.

Othman Puteh. (1989). Sastera remaja ditinjau daripada beberapa perspektif. Kuala Lumpur: Dewan Bahasa dan Pustaka.

Ummu Hani Abu Hassan. (2009). Satu bulan tiga bintang. Kuala Lumpur: Galeri Ilmu Sdn. Bhd.

Received: 10 August 2017

Accepted: 27 September 2017 